JURNAL NOMINAL / VOLUME VII NOMOR 2 / TAHUN 2018

\title{
PENGARUH PENGUNGKAPAN SUSTAINABILITY REPORT DAN UKURAN PERUSAHAAN TERHADAP NILAI PERUSAHAAN DENGAN PROFITABILITAS SEBAGAI VARIABEL PEMODERASI PADA PERUSAHAAN YANG BERGABUNG DI ISSI DAN KONVENSIONAL PERIODE 2014-2016
}

\section{THE INFLUENCE OF SUSTAINABILITY REPORT DISCLOSURE AND COMPANY'S SIZE ON COMPANY'S VALUE WITH PROFITABILITY AS A MODERNATION VARIABLE IN THE COMPANY JOINING IN ISSI AND CONVENTIONAL IN THE PERIOD 2014-2016}

\author{
Rr. Aurin Wahyu Kusuma \\ Prodi Akuntansi Universitas Negeri Yogyakarta \\ ririendkusuma@gmail.com \\ Dr. Denies Priantinah, M.Si., AK., CA. \\ Staf Pengajar Jurusan Pendidikan Akuntansi Universitas Negeri Yogyakarta \\ denies_priantinah@uny.ac.id
}

\begin{abstract}
Abstrak : Pengaruh Pengungkapan Sustainability Report Dan Ukuran Perusahaan Terhadap Nilai Perusahaan Dengan Profitabilitas Sebagai Variabel Pemoderasi Pada Perusahaan Yang Bergabung Di Issi Dan Konvensional Periode 2014-2016. Penelitian ini bertujuan untuk mengetahui (1) pengaruh Pengungkapan Sustainability Report terhadap Nilai Perusahaan, (2) pengaruh Ukuran Perusahaan terhadap Nilai Perusahaan, (3) pengaruh Pengungkapan Sustainability Report terhadap Nilai Perusahaan dengan Profitabilitas sebagai variabel pemoderasi, (4) pengaruh Ukuran Perusahaan terhadap Nilai Perusahaan dengan Profitabilitas sebagai variabel pemoderasi, (5) dan perbedaan Pengungkapan Sustainability Report, Ukuran Perusahaan, Nilai Perusahaan, dan Profitabilitas antara perusahaan yang bergabung di ISSI dan Konvensional. Metode penelitian yang digunakan adalah metode penelitian kausal komparatif. Populasi dalam penelitian adalah 560 perusahaan go public periode 2014-2016. Sampel penelitian ini berjumlah 45 perusahaan yang diperoleh dengan metode purposive sampling. Teknik analisis yang digunakan adalah analisis regresi sederhana, analisis regresi uji nilai selisih mutlak, dan analisis regresi berganda. Hasil penelitian ini menunjukkan bahwa (1) Pengungkapan Sustainability Report berpengaruh positif dan tidak signifikan terhadap Nilai Perusahaan, (2) Ukuran Perusahaan berpengaruh negatif dan tidak signifikan terhadap Nilai Perusahaan, (3) Profitabilitas tidak mampu memoderasi pengaruh Pengungkapan Sustainability Report terhadap Nilai Perusahaan, (4) Profitabilitas tidak mampu memoderasi pengaruh Ukuran Perusahaan terhadap Nilai Perusahaan, (5) Pengungkapan Sustainability Report dan Ukuran Perusahaan secara bersama-sama tidak berpengaruh terhadap Nilai Perusahaan, (6) Terdapat perbedaan Pengungkapan Sustainability Report, Ukuran Perusahaan, Nilai Perusahaan, dan Profitabilitas antara perusahaan yang bergabung di ISSI dan konvensional.
\end{abstract}

Kata kunci: Sustainability Report, Ukuran Perusahaan, Nilai Perusahaan, Profitabilitas.

Abstract : The Influence Of Sustainability Report Disclosure And Company's Size On Company's Value With Profitability As A Modernation Variable In The Company Joining In Issi And Conventional In The Period 2014-2016. This study aims to determine (1) the influence of Sustainability Report disclosure on Company's Value, (2) the influence of Company's Size on Company's Value, (3) the influence of Sustainability Report disclosure on Company's Value with Profitability as moderate variable, (4) the influence of Company's Size on the Company's Value with Profitability as moderate variable, (5) and the difference of Sustainability Report disclosure, company's size, company's value and the profitability of the companies that join ISSI and conventional. The research method uses comparative causal research method. The population in this study is 560 go public-companies in the period of 2014-2016. The sample in this study is 45 companies from purposive sampling method. The writer uses simple regression analysis, absolute difference value test regression analysis, and multiple regression analysis. The results of this study indicate that (1) Sustainability Report Disclosure has positive and insignificant influence on Company's Value, (2) Company's Size has negative and insignificant influence on Company's Value, (3) Profitability can 


\section{JURNAL NOMINAL / VOLUME VII NOMOR 2 / TAHUN 2018}

not moderate the influence of Sustainability Report Disclosure on the Company's Value, 4) Profitability can not moderate the influence of Company's Size on Company's Value, (5) Simultaneously Sustainability Report Disclosure and Company's Size do not influence on Company's Value, (6) there are differences in Sustainability Report Disclosure, Company's Size, Company's Value, and Profitability in the companies that join ISSI and conventional.

Keywords: Sustainability Report, Company's Size, Company's Value, Profitability.

\section{PENDAHULUAN}

Perkembangan dunia bisnis semakin berkembang pesat ditandai dengan munculnya perusahaan dengan sektor yang beraneka ragam. Hal tersebut mengakibatkan tingkat persaingan antara pelaku bisnis semakin ketat. Persaingan akan mempengaruhi aktivitas bisnis yang lebih berorientasi pada keuntungan semata tanpa mempedulikan dampak negatif dari aktivitas tersebut. Pelaku bisnis yang hanya berorientasi pada laba (profit) sebagai tujuan jangka pendek, maka perusahaan tersebut tidak akan mampu survive dalam jangka waktu yang panjang (Ernawan, 2011: 158).

Persaingan merupakan suatu hal yang wajar. Adanya persaingan tersebut mengakibatkan pelaku bisnis selalu berupaya untuk meningkatkan nilai perusahaan agar mampu survive dalam jangka panjang. Nilai perusahaan berkaitan dengan harga saham. Secara teoretis, nilai perusahaan dapat dikatakan baik apabila harga sahamnya tinggi (Kusumadilaga, 2010: 7). Hubungan diantara keduanya adalah berbanding lurus. Apabila harga saham naik, maka nilai perusahaan juga akan meningkat. Begitu pula sebaliknya, apabila harga saham menurun maka nilai perusahaan juga akan menurun. Dengan demikian, perusahaan berupaya melakukan peningkatan kemakmuran pemegang saham untuk meningkatkan nilai perusahaan.

Keberadaan perusahaan berkaitan dengan kondisi perekonomian suatu negara yang akan menentukan kualitas hidup masyarakat. Apabila perekonomian suatu negara meningkat, maka kualitas hidup masyarakat juga akan meningkat. Untuk meningkatkan perekonomian negara tersebut, perusahaan membutuhkan sumber daya alam yang lebih. Selain itu, semakin banyak jumlah penduduk maka semakin banyak pula barang dan jasa yang dibutuhkan oleh masyarakat. Semakin tinggi kebutuhan masyarakat, maka semakin tinggi pula sumber daya alam yang akan diambil oleh para pelaku bisnis. Selanjutnya, sumber daya alam yang tersedia di bumi akan menipis dan menimbulkan pencemaran lingkungan. Jadi, selain memberikan dampak positif, perkembangan dunia bisnis juga dapat memberikan dampak negatif (Arijanto, 2012: 115).

Undang-Undang tentang Perseroan Terbatas No. 40 Tahun 2007 mewajibkan suatu perusahaan untuk melakukan 


\section{JURNAL NOMINAL / VOLUME VII NOMOR 2 / TAHUN 2018}

kegiatan tanggung jawab sosial. Selain itu, terdapat Undang-Undang tentang Perlindungan dan Pengelolaan Lingkungan Hidup, yaitu Undang-Undang No. 32 Tahun 2009. Sementara ketentuan pidana atau sanksi yang terkait dengan Tanggung Jawab Sosial dan Lingkungan terdapat pada Undang-Undang No. 32 Tahun 1997 (www.hukumonline.com).

Kesenjangan sosial dan kerusakan lingkungan di bumi terjadi karena pelaku bisnis kurang memperhatikan dan mempedulikan keadaan sosial dan lingkungan sekitar. Fenomena tersebut mengakibatkan terjadinya pergeseran orientasi operasi ke arah stakeholders, khususnya stakeholders eksternal yang dianggap lebih mendukung perusahaan. Wujud pergeseran tersebut ditunjukkan dengan cakupan luas mengenai pengungkapan tanggung jawab sosial. Akan tetapi, hanya $30 \%$ dari seluruh perusahaan yang penuh keseriusan menggeser pola oreintasi ke stakeholders menjadi bagian dari strategi perusahaan. Sementara sisanya (70\%) hanya sebatas memenuhi standar aturan bahwa perusahaan mengungkapkan tanggung jawab sosial seperti perusahaan lain (Hadi, 2011: 152). Sustainability Report merupakan salah satu bentuk tanggung jawab perusahaan yang memperhatikan aspek ekonomi, sosial, dan lingkungan. Sustainability Report dianggap penting karena mampu menunjukkan transparansi kepada stakeholders yang dapat meningkatkan kepercayaan masyarakat terhadap perusahaan, sehingga nilai perusahaan juga dapat meningkat (Astuti \& Juwenah, 2017: 302).

$$
\text { Selain dipengaruhi oleh }
$$

Sustainability Report (SR), nilai perusahaan juga dapat dipengaruhi oleh ukuran perusahaan. Dalam penelitian yang dilakukan oleh Aditama (2015: 82) ternyata ukuran perusahaan berpengaruh positif signifikan terhadap nilai perusahaan. Perusahaan yang memiliki ukuran yang besar menunjukkan bahwa perusahaan dalam kondisi yang stabil. Perusahaan yang besar memiliki aset yang besar pula, sehingga memiliki tanggung jawab terhadap para pemangku kepentingan, seperti masyarakat. Berbeda dengan penelitian yang dilakukan oleh Suffah dan Riduwan (2016: 16). Penelitian tersebut menunjukkan hasil bahwa ukuran perusahaan yang diukur dengan menggunakan total aset tidak berpengaruh pada nilai perusahaan. Pengukuran yang dilakukan oleh kedua penelitian tersebut tidak berbeda, yaitu menggunakan total aset perusahaan. Akan tetapi, hasil yang diperoleh dari kedua penelitian tersebut berbeda.

Profitabilitas juga berperan penting dalam penelitian ini, karena pada umumnya kemampuan perusahaan dalam menghasilkan laba akan berpengaruh pada kegiatan perusahaan. Secara teoretis, 


\section{JURNAL NOMINAL / VOLUME VII NOMOR 2 / TAHUN 2018}

semakin tinggi tingkat profitabilitas perusahaan maka semakin tinggi pula hubungan pengungkapan sosial dengan nilai perusahaan (Kusumadilaga, 2010: 6). Dengan demikian, profitabilitas yang semakin tinggi akan meningkatkan hubungan antara pengungkapan Sustainability Report dengan nilai perusahaan.

Suatu perusahaan pasti mempunyai tujuan demi memperoleh keuntungan dan keberlangsungan usahanya. Perusahaan akan merencanakan suatu strategi demi mencapai tujuan yang telah ditetapkan. Pada akuntansi konvensional, perusahaan berpusat pada kepentingan stockholder dan bondholders (Arijanto, 2012: 137). Hal tersebut secara langsung akan memberikan kontribusinya bagi perusahaan, sementara pihak-pihak di luar itu akan terabaikan. Selain itu, perkembangan ekonomi konvensional juga pernah memberikan dampak buruk bagi perekonomian nasional, khususnya pada perbankan konvensional. Kepercayaan nasabah terhadap bank konvensional turun drastis. Ketika krisis ekonomi muncul, hanya ada satu bank yang mampu bertahan menghadapinya, yaitu Bank Muamalat. Bank Muamalat mempunyai sistem bagi hasil (mudharabah) yang tidak ada di bank konvensional. Berdasarkan keberhasilan Bank Muamalat dalam mengahadapi krisis ekonomi, secara perlahan para ahli mengubah orientasi pemikirannya ke arah ekonomi syariah (Ali, 2008: 61). Berawal dari fenomena ekonomi tersebut, maka mulai banyak bermunculan perusahaan yang beralih ke orientasi ekonomi bebasis syariah.

Berdasarkan latar belakang yang telah dipaparkan pada paragraf sebelumnya, peneliti melakukan penelitian dengan judul "Pengaruh Pengungkapan Sustainability Report dan Ukuran Perusahaan terhadap Nilai Perusahaan dengan Profitabilitas sebagai Variabel Pemoderasi pada Perusahaan yang Bergabung di ISSI dan Konvensional Periode 2014-2016. Penelitian ini akan menggunakan data yang diperoleh dari Laporan Keuangan (Financial Report) dan Laporan Keberlanjutan (Sustainability Report).

\section{METODE PENELITIAN}

\section{Jenis Penelitian}

Penelitian ini menggunakan metode penelitian kausal-komparatif, yaitu identifikasi hubungan sebab-akibat (antara variabel dependen dan variabel independen) dan melakukan perbandingan (Kuncoro, 2003: 252).

\section{Waktu dan Tempat Penelitian}

Penelitian ini dilakukan dengan mengambil data di Bursa Efek Indonesia (BEI) melalui website www.idx.co.id, dan finace.yahoo.com, serta melalui website masing-masing perusahaan. Sumber data penelitian ini merupakan data sekunder 


\section{JURNAL NOMINAL / VOLUME VII NOMOR 2 / TAHUN 2018}

yang diperoleh dari laporan keuangan dan laporan keberlanjutan (Sustainability Report) perusahaan yang terdaftar di Bursa Efek Indonesia (BEI) periode 2014-2016. Penelitian ini dilaksanakan pada bulan Januari sampai dengan bulan Maret tahun 2018.

\section{Populasi dan Sampel Penelitian}

Populasi dalam penelitian ini adalah seluruh perusahaan yang terdaftar dalam Bursa Efek Indonesia (BEI) periode 20142016. Sampel dalam penelitian ini berjumlah 45 perusahaan yang diperoleh dengan menggunakan teknik purposive sampling. Dengan karakteristik sampel sebagai berikut:

a. Perusahaan yang terdaftar dalam Bursa Efek Indonesia periode 2014-2016.

b. Perusahaan yang menerbitkan laporan keuangan secara berturut-turut pada periode 2014-2016.

c. Perusahaan yang menerbitkan laporan keberlanjutan (Sustainability Report).

d. Mempunyai data lengkap terkait dengan variabel-variabel yang digunakan oleh peneliti dalam melakukan penelitian.

\section{Definisi Operasional Variabel}

a. Nilai Perusahaan

Nilai perusahaan merupakan persepsi para investor terhadap tingkat keberhasilan suatu perusahaan yang tercermin pada harga saham perusahaan tersebut. Nilai Perusahaan dapat diproksikan dengan menggunakan pengukuran Price to Book
Value (PBV). Berikut adalah rumus PBV

(Tjiptono dan Fakhruddin, 2012):

$P B V=\frac{\text { Harga Pasar per Lembar Saham }}{\text { Nilai Buku per Lembar Saham }}$

Nilai Buku per Lembar Saham

$=\frac{\text { Total Equitas }}{\text { Jumlah Lembar Saham Beredar }}$

b. Pengungkapan Sustainability Report Sustainability Report menurut Global Report Initiatiive G4 tahun 2013 adalah laporan keberlanjutan yang dikeluarkan oleh perusahaan mengenai dampak ekonomi, lingkungan dan sosial yang disebabkan oleh aktivitas sehari-hari. Pengungkapan Sustainability Report dapat dilakukan menggunakan perhitungan Sustainability Report Disclosure Index (SRDI). Rumus perhitungan Sustainability Report Disclosure Index adalah:

$$
S R D I_{j}=\frac{n}{k}
$$

Keterangan:

$$
\begin{aligned}
\text { SRDI = } & \text { Sustainability Report Disclosure } \\
& \text { Index perusahaan } \\
\mathrm{N}= & \text { Total item yang diungkapkan oleh } \\
& \text { perusahaan } \\
k \quad & \text { Total keseluruhan item yang } \\
& \text { disyaratkan oleh GRI, } \mathrm{k}=91
\end{aligned}
$$

c. Ukuran Perusahaan

Ukuran perusahaan dapat dikatakan sebagai suatu cerminan total aset atau kekayaan yang dimiliki oleh suatu perusahaan. Penelitian ini menggunakan besarnya aset yang dimiliki perusahaan untuk menilai Ukuran Perusahaan. Rumus 
JURNAL NOMINAL / VOLUME VII NOMOR 2 / TAHUN 2018

yang digunakan peneliti dalam menilai ukuran perusahaan adalah sebagai berikut (Suffah \& Riduwan, 2016:9):

\section{Ukuran Perusahaan \\ $=\log$ Natural (Ln) of Total Aset}

d. Profitabilitas

Profitabilitas merupakan kemampuan perusahaan menghasilkan laba dari kegiatan opersasional. Penelitian ini mengukur profitabilitas menggunakan rasio Return on Aset (ROA) yang diperoleh dari laporan keuangan perusahaan selama periode 2014-2016. Menurut Brigham dan Houston (2010:146) ROA dapat dihitung menggunakan rumus:

$$
R O A=\frac{\text { Laba bersih }}{\text { Total Aset }}
$$

Data, Instrumen, dan Teknik Pengumpulan

Data

Jenis data yang digunakan dalam penelitian ini adalah data kuantitatif. Data kuantitatif adalah data yang mengacu pada perhitungan angka. Metode pengumpulan data yang digunakan dalam penelitian ini adalah metode dokumentasi. Menurut Deriyaso (2014: 38), metode dokumentasi yaitu teknik pengumpulan data yang dilakukan dengan mencari, mengumpulkan, mencatat, dan mengkaji data mengenai hal yang terkait melalui catatan, surat kabar, buku, situs website, dokumen, dan lain sebagainya.
Dokumentasi digunakan untuk memperoleh data Nilai perusahaan, Sustainability Report, Ukuran Perusahaan, dan Profitabilitas.

\section{Teknik Analisis Data}

Teknik analisis data menggunakan analisis statistik deskriptif, uji asumsi klasik, analisis regresi linier sederhana, analisis regresi uji nilai selisih mutlak, dan analisis regresi linier berganda.

\section{HASIL PENELITIAN DAN PEMBA- HASAN}

\section{Analisis Statistik Deskriptif}

a. Nilai Perusahaan

Tabel 1.Hasil Statistik Deskriptif Nilai Perusahaan

\begin{tabular}{cccccc}
\hline & $\mathrm{N}$ & Min & Max & Mean & Std. \\
& & & & & Dev \\
$\mathrm{P}$ & 11 & - & 5,09 & 1,539 & 1,21 \\
$\mathrm{~B}$ & 8 & 0,801 & 040 & 4437 & 4358 \\
$\mathrm{~V}$ & & 5646 & 41 & 68 & 0573 \\
\hline
\end{tabular}

Sumber: Data sekunder yang diolah

Variabel Nilai Perusahaan yang diproksikan dengan Price to Book Value (PBV). Berdasarkan tabel 1, dapat diketahui bahwa nilai minimum Price to Book Value (PBV) periode 2014-2016 sebesar -0,8015646 dan nilai maksimum sebesar 5,0904041. Hal ini menunjukkan bahwa tingkat minimum keberhasilan perusahaan adalah $-80 \%$ dari harga saham dan tingkat maksimum keberhasilan perusahaan adalah 509\% dari harga saham. Nilai rata-rata PBV adalah 1,539443768 dengan standar deviasi 1,2143580573. Hal 
JURNAL NOMINAL / VOLUME VII NOMOR 2 / TAHUN 2018

ini berarti bahwa rata-rata perusahaan sampel memiliki tingkat keberhasilan 1,539443768 atau $153 \%$ dari harga saham.

b. Sustainability Report

Tabel 2. Hasil Statistik Deskriptif Pengungkapan Sustainability Report

\begin{tabular}{cccccc} 
& $\mathrm{N}$ & Min & Max & Mea & Std. \\
& & & & $n$ & Dev \\
$\mathrm{S}$ & 11 & 0,054 & 0,94 & 0,33 & 0,18 \\
$\mathrm{R}$ & 8 & 9451 & 505 & 2091 & 071 \\
& & & 49 & 637 & 720 \\
& & & & & 49 \\
\hline
\end{tabular}

Sumber: Data sekunder yang diolah

Berdasarkan tabel 2, dapat diketahui bahwa nilai minimum Pengungkapan Sustainability Report periode 2014-2016 sebesar 0,0549451 dan nilai maksimum sebesar 0,9450549. Hal ini berarti pengungkapan Sustainability Report mulai dari yang sangat rendah sampai dengan yang tinggi. Nilai rata-rata (mean) sebesar 0,332091637 dan standar deviasi sebesar 0,1807172049 . Hal tersebut berarti ratarata perusahaan sampel dalam mengungkapkan kegiatan tanggung jawab sosial sebesar 33\%, yang menunjukkan tingkat pengungkapan Sustainability Report cukup baik.

c. Ukuran Perusahaan

Tabel 3. Hasil Statistik Deskriptif Ukuran Perusahaan

\begin{tabular}{cccccc}
\hline & N & Min & Max & Mea & Std. \\
& & & & $n$ & Dev \\
Si & 11 & 28,54 & 34,5 & 31,4 & 1,37 \\
ze & 8 & 07892 & 767 & 8081 & 7584 \\
\hline
\end{tabular}

$521 \quad 202$

6156

Sumber: Data sekunder yang diolah

Berdasarkan tabel 3, dapat diketahui bahwa nilai minimum Ukuran Perusahaan sebesar 28,5407892 dan nilai maksimum sebesar 34,5767521. Hal tersebut menunjukkan bahwa kekayaan yang dimiliki perusahaan berkisar antara 28,5407892 hingga 34,5767521 . Nilai ratarata (mean) sebesar 31,48081202 dan standar deviasi sebesar 1,3775846156. Hal tersebut artinya bahwa rata-rata kekayaan yang dimiliki perusahaan sebesar 31,48081202 dari total aset perusahaan.

d. Profitabilitas

Tabel 4. Hasil Statistik Deskriptif Profitabilitas

\begin{tabular}{lccccc}
\hline & N & Min & Max & Mean & $\begin{array}{l}\text { Std. } \\
\text { Dev }\end{array}$ \\
& & & & & \\
RO & 11 & - & 0,17 & 0,034 & 0,07 \\
A & 8 & 0,52 & 842 & 2575 & 310 \\
& & 195 & 41 & 78 & 170 \\
& & 03 & & & 91 \\
\hline
\end{tabular}

Sumber: Data sekunder yang diolah

Profitabilitas ditunjukkan oleh proksi Return on Asset (ROA). Berdasarkan tabel 4, dapat diketahui bahwa nilai minimum ROA pada sampel penelitian ini sebesar 0,5219503 dan nilai maksimum sebesar 0,1784241. Hal tersebut menunjukkan bahwa besarnya nilai ROA pada sampel penelitian ini berkisar antara $-52 \%$ sampai $17 \%$, yang menunjukkan bahwa perusahaan dapat menghasilkan laba minimum sebesar $-52 \%$ dari total aset dan 


\section{JURNAL NOMINAL / VOLUME VII NOMOR 2 / TAHUN 2018}

perusahaan dapat menghasilkan laba maksimum sebesar $17 \%$ dari total aset. Nilai rata-rata (mean) ROA sebesar 0,034257578 dan standar deviasi sebesar 0,0731017091. Hal tersebut berarti bahwa rata-rata perusahaan sampel dalam menghasilkan laba sebesar $0,3 \%$ dari total aset yang dimiliki perusahaan.

\section{Uji Asumsi Klasik}

a. Uji Normalitas

Tabel 5. Ringkasan Hasil Uji Normalitas

\begin{tabular}{ccc}
\hline Variabel & $\begin{array}{c}\text { Asymp. Sig. } \\
\text { (2-tailed) }\end{array}$ & Kesimpulan \\
Unstandardize & 0,200 & Normal \\
d Residual & &
\end{tabular}

Sumber: Data sekunder yang diolah

Berdasarkan hasil uji normalitas pada tabel 5, menunjukkan bahwa variabel Nilai Perusahaan memiliki nilai Asymp. Sig. (2tailed) sebesar 0,200. Nilai tersebut lebih besar dari 0,05. Dengan demikian, dapat disimpulkan bahwa data dalam model regresi penelitian ini berdistribusi normal.

b. Uji Multikolinieritas

Tabel 6. Ringkasan Hasil Uji Multikolinieritas

\begin{tabular}{lrl}
\hline \multicolumn{1}{c}{ Variabel } & Tolerance & VIF \\
SR & 0,950 & 1,053 \\
Size & 0,988 & 1,012 \\
ROA & 0,942 & 1,061 \\
\hline
\end{tabular}

Sumber: Data sekunder yang diolah

Berdasarkan hasil uji multikolinieritas, nilai Tolerance lebih besar dari 0,10. Hasil perhitungan nilai Variance Inflation Factor (VIF) berada di bawah nilai 10. Dengan demikian, dapat

disimpulkan bahwa model regresi penelitian ini tidak terjadi multikolinieritas.

c. Uji Autokorelasi

Tabel 7. Ringkasan Hasil Uji Autokorelasi

\begin{tabular}{ccccc}
\hline Model & $\mathrm{k}: \mathrm{N}$ & $\mathrm{dU}$ & 4-dU & $\begin{array}{c}\text { Durbin } \\
- \\
\end{array}$ \\
& & & & \\
Value & 118 & 1,7702 & 2,2298 & 1,836
\end{tabular}

Sumber: Data sekunder yang diolah

Berdasarkan hasil uji autokorelasi nilai Durbin-Watson adalah sebesar 1,836, dU = 1,7702, dan 4-dU = 2,2298. Nilai DurbinWatson sebesar 1,836 berada di antara 1,7702 sampai 2,2298. Dengan demikian, dapat disimpulkan bahwa residual random atau tidak terjadi autokorelasi antarnilai residual.

d. Uji Heteroskedastisitas

Tabel 8. Ringkasan Hasil Uji Heteroskedastisitas

\begin{tabular}{lc}
\hline \multicolumn{1}{c}{ Model Sig. } \\
(Constant) & 0,621 \\
SR & 0,056 \\
Size & 0,505 \\
ROA & 0,284 \\
\hline Sumber: Data sekunder yang diolah \\
\multicolumn{2}{c}{ Berdasarkan hasil } \\
heteroskedastisitas, nilai signifikansi dari \\
variabel Sustainability Report sebesar \\
0,056, variabel Ukuran Perusahaan sebesar \\
0,505, dan variabel Profitabilitas sebesar \\
0,284. Nilai sisgifikansi tersebut berada di \\
atas 0,05. Dengan demikian, dapat
\end{tabular}




\section{JURNAL NOMINAL / VOLUME VII NOMOR 2 / TAHUN 2018}

disimpulkan bahwa model regresi tidak mengandung adanya heteroskedastisitas.

e. Uji Linieritas

Tabel 9 Ringkasan Hasil Uji Linieritas

\begin{tabular}{lcrc}
\hline Model & $\mathrm{R}^{2}$ & $\mathrm{C}^{2}$ hitung & $\mathrm{C}^{2}$ tabel \\
ROA2, & 0,017 & 2,006 & 143,246 \\
SR2, & & & \\
Size2 & & & \\
\hline
\end{tabular}

Sumber: Data sekunder yang diolah

Berdasarkan hasil uji linieritas, nilai $\mathrm{C}^{2}$ hitung lebih kecil dari nilai $\mathrm{C}^{2}$ tabel sebesar 143,246. Dengan demikian, dapat disimpulkan bahwa model regresi dalam penelitian ini adalah model linier.

\section{Pengujian Hipotesis}

1) Pengujian Hipotesis Pertama

Ringkasan uji hipotesis pertama dapat dilihat pada tabel berikut:

Tabel 10. Hasil Pengujian Hipotesis Pertama

\begin{tabular}{ll}
\hline \multicolumn{1}{c}{ Informasi } & \multicolumn{1}{c}{ Nilai } \\
\hline Konstanta & 0,329 \\
\hline Koefisien & 0,206 \\
\hline $\mathbf{r}^{\mathbf{2}}$ & 0,003 \\
\hline $\mathbf{t}_{\text {hitung }}$ & 0,567 \\
\hline $\mathbf{t}_{\text {tabel }}$ & 1,658 \\
\hline Sig. & 0,572 \\
\hline \multicolumn{1}{c}{ Berdasarkan nilai } & konstanta dan
\end{tabular}

koefisien regresi pada Tabel 10 maka persamaan regresi untuk hipotesis pertama adalah:

$$
P B V=0,329+0,206 S R
$$

Koefisien regresi sebesar 0,206 dan nilai thitung sebesar 0,567 yang mana lebih kecil dari tabel 1,658. Tingkat signifikansi sebesar 0,572 menunjukkan nilai yang lebih besar dari 0,05. Hal ini menunjukkan bahwa Pengungkapan Sustainability Report (SR) berpengaruh positif dan tidak signifikan terhadap Nilai Perusahaan (PBV).

Berdasarkan hasil penelitian ini menunjukkan bahwa pengungkapan Sustainability Report selama tiga periode pengamatan belum menunjukkan hasil yang maksimal. Hal tersebut ditandai dengan beberapa hal, pertama kurangnya perusahaan mengikuti standar yang dikeluarkan oleh GRI. Kedua, tidak semua perusahaan mengungkapkan kegiatan sosialnya pada Sustainability Report. Ketiga, perusahaan yang telah mengungkapkan Sustainability Report belum diterbitkan secara konsisten setiap tahun. Keempat, Undang-Undang Nomor 40 Tahun 2007 mengenai Perseroan Terbatas belum sepenuhnya memberikan pengaruh terhadap pengungkapan Sustainability Report pada perusahaan go public secara konsisten selama tiga periode pengamatan. Dengan demikian, tingkat pengungkapan Sustainability Report tergolong rendah dan memberikan pengaruh yang tidak signifikan terhadap Nilai Perusahaan.

2) Pengujian Hipotesis Kedua

Ringkasan uji hipotesis kedua dapat dilihat pada tabel berikut: 
JURNAL NOMINAL / VOLUME VII NOMOR 2 / TAHUN 2018

Tabel 11. Hasil Pengujian Hipotesis Kedua

\begin{tabular}{ll}
\multicolumn{1}{c}{ Informasi } & \multicolumn{1}{c}{ Nilai } \\
\hline Konstanta & 1,285 \\
\hline Koefisien & $-0,616$ \\
\hline $\mathbf{r}^{2}$ & 0,003 \\
\hline $\mathbf{t}_{\text {hitung }}$ & $-0,554$ \\
\hline $\mathbf{t}_{\text {tabel }}$ & 1,658 \\
\hline Sig. & 0,581 \\
\hline \multicolumn{1}{c}{ Berdasarkan nilai } & konstanta dan
\end{tabular}

koefisien regresi pada Tabel 11 maka persamaan regresi untuk hipotesis kedua adalah:

$$
P B V=1,285-0,616 \text { Size }
$$

Koefisien regresi sebesar $-0,616$ menunjukkan bahwa Ukuran Perusahaan berpengaruh negatif terhadap Nilai Perusahaan (PBV). Nilai thitung adalah sebesar -0,554 yang mana lebih kecil dari $t_{\text {tabel }}$ 1,658. Tingkat signifikansi sebesar 0,581 menunjukkan nilai yang lebih besar dari 0,05. Hal ini menunjukkan bahwa Ukuran Perusahaan berpengaruh negatif dan tidak signifikan terhadap Nilai Perusahaan (PBV).

Upaya perusahaan untuk memperbesar ukuran perusahaan adalah melalui peningkatan jumlah aset perusahaan. Aset perusahaan yang diperoleh melalui utang akan menimbulkan kekhawatiran bagi para investor. Hal tersebut disebabkan karena tingginya risiko perusahaan, sehingga mampu memperbesar potensi terjadinya kebangkrutan. Dengan demikian, Ukuran Perusahaan bukanlah menjadi hal penting dalam pengambilan keputusan investor sehingga Nilai Perusahaan juga akan menurun.

\section{3) Pengujian Hipotesis Ketiga Ringkasan uji hipotesis ketiga dapat dilihat pada tabel berikut:}

Tabel 12. Hasil Pengujian Hipotesis Ketiga

\begin{tabular}{lcccccc}
\hline Variab & Kons & Koefisi & $\mathrm{r}^{2}$ & & Nilai t & \\
el & tanta & en & & thitung & $\mathrm{t}$ & Sig. \\
ZSR & 0,357 & $-0,018$ & 0,3 & - & 1,980 & 0,310 \\
& & & 91 & 1,020 & & \\
ZROA & & 0,139 & & 6,254 & & 0,000 \\
AbsS & & $-0,004$ & & - & & 0,884 \\
R_RO & & & & 0,146 & &
\end{tabular}

A

Berdasarkan nilai konstanta dan koefisien regresi pada tabel 12 maka persamaan regresi untuk hipotesis ketiga adalah:

$$
\begin{array}{r}
P B V=0,357-0,018 S R+0,139 \text { ROA } \\
-0,004|S R-R O A|
\end{array}
$$

Koefisien regresi sebesar $-0,004$ menunjukkan bahwa variabel interaksi antara Pengungkapan Sustainability Report (SR) dan Profitabilitas berpengaruh negatif terhadap Nilai Perusahaan (PBV). Nilai thitung sebesar -0,146 lebih kecil dibandingkan dengan $t_{\text {tabel }}$ sebesar 1,980. Tingkat signifikansi sebesar $\quad 0,884$ menunjukkan nilai yang lebih besar dari 0,05. Hal ini menunjukkan bahwa Profitabilitas tidak mampu memoderasi hubungan Pengungkapan Sustainability Report (SR) terhadap Nilai Perusahaan (PBV). 


\section{JURNAL NOMINAL / VOLUME VII NOMOR 2 / TAHUN 2018}

Semakin meningkatnya profitabilitas perusahaan akan menyebabkan perusahaan lebih berhati-hati dalam menggunakan kekayaan perusahaan. Hal tersebut terjadi karena adanya risiko yang harus ditanggung oleh perusahaan. Berdasarkan hasil penelitian, tingkat profitabilitas perusahaan tidak mampu untuk meningkatkan kegiatan perusahaan dalam hal tanggung jawab sosial. Hal tersebut ditunjukkan dengan jumlah perusahaan yang menerbitkan Sustainability Report yang masih tergolong rendah. Selain itu, pengungkapan kegiatan tanggung jawab sosial masih dibawah standar dan penerbitan laporan yang belum konsisten di setiap tahunnya. Dengan demikian, Profitabilitas tidak mampu memoderasi pengaruh pengungkapan Sustainability Report (SR) terhadap Nilai Perusahaan.

\section{4) Pengujian Hipotesis Keempat}

Ringkasan uji hipotesis keempat dapat dilihat pada tabel berikut:

Tabel 13. Hasil Pengujian Hipotesis Keempat

\begin{tabular}{|c|c|c|c|c|c|c|}
\hline \multirow[t]{3}{*}{ Variabel } & Kon & Koefisi & r2 & & Nilai t & \\
\hline & stant & en & & thitung & $\mathrm{t}$ & Sig. \\
\hline & a & & & & & \\
\hline \multirow[t]{2}{*}{ ZSize } & 0,33 & $-0,024$ & 0,40 & $-1,492$ & 1,98 & 0,138 \\
\hline & 0 & & 5 & & 0 & \\
\hline ZROA & & 0,148 & & 8,433 & & 0,000 \\
\hline AbsSize & & 0,024 & & 1,258 & & 0,211 \\
\hline \multicolumn{7}{|l|}{ ROA } \\
\hline & \multicolumn{2}{|c|}{ Berdasarkan } & nilai & \multicolumn{2}{|c|}{ konstanta } & dan \\
\hline $\mathrm{kO}$ & isien & regresi & pada & tabe & 13 & maka \\
\hline
\end{tabular}

persamaan regresi untuk hipotesis keempat adalah:

$$
\begin{array}{r}
P B V=0,330-0,024 \text { Size }+0,148 \text { ROA } \\
+0,024 \mid \text { Size }- \text { ROA } \mid
\end{array}
$$

Koefisien regresi sebesar 0,024 menunjukkan bahwa variabel interaksi antara Ukuran Perusahaan dan Profitabilitas berpengaruh positif terhadap Nilai Perusahaan (PBV). Nilai thitung sebesar 1,258 lebih kecil dari tabel 1,980. Tingkat signifikansi sebesar 0,211 lebih besar dari 0,05. Hal ini menunjukkan bahwa Profitabilitas tidak mampu memoderasi hubungan Ukuran Perusahaan terhadap Nilai Perusahaan (PBV).

Semakin meningkatnya profitabilitas perusahaan akan menyebabkan perusahaan lebih berhati-hati dalam menggunakan kekayaan perusahaan. Hal tersebut terjadi karena adanya risiko yang harus ditanggung oleh perusahaan. Perusahaan yang mempunyai jumlah kewajiban tinggi, maka perusahaan akan menggunakan sebagian laba yang dimiliki untuk memenuhi kewajiban perusahaan. Dengan demikian, profitabilitas tidak mampu memoderasi Ukuran Perusahaan terhadap Nilai Perusahaan.

\section{5) Pengujian Hipotesis Kelima \\ Ringkasan uji hipotesis kelima dapat} dilihat pada tabel berikut: 
JURNAL NOMINAL / VOLUME VII NOMOR 2 / TAHUN 2018

Tabel 24. Hasil Pengujian Hipotesis Kelima

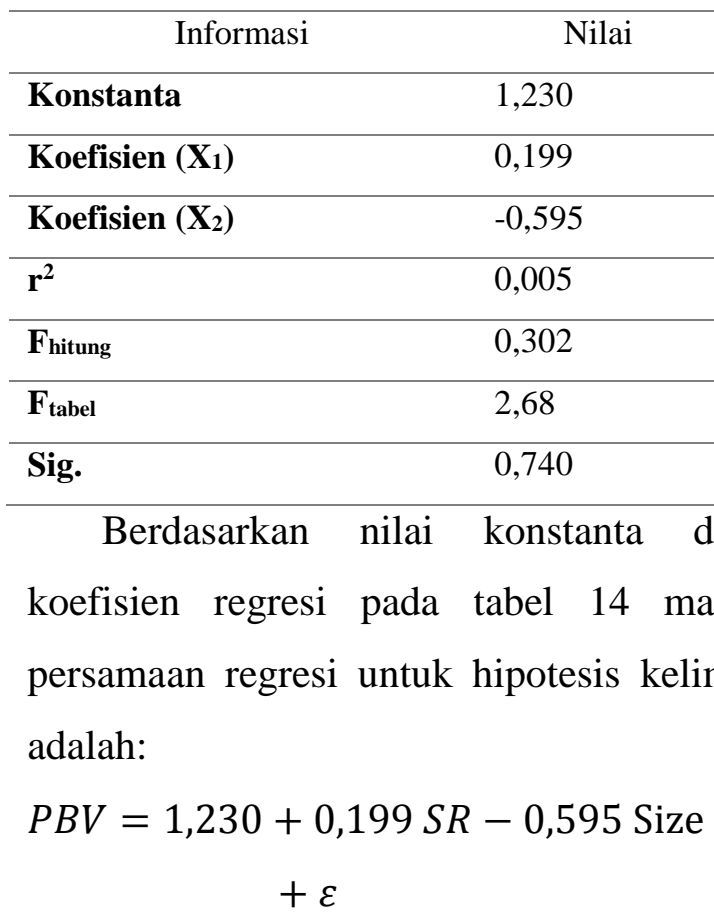

Berdasarkan tabel 14 dapat diketahui bahwa nilai $F_{\text {hitung }}$ sebesar 0,302 lebih kecil dari $F_{\text {tabel }}$ sebsar 2,68. Tingkat signifikansi sebesar 0,740 menunjukkan nilai yang lebih besar dari 0,05 . Hal ini menunjukkan bahwa Pengungkapan Sustainability Report (SR) dan Ukuran Perusahaan secara bersama-sama tidak berpengaruh terhadap Nilai Perusahaan (PBV).

Pengungkapan Sustainability Report (SR) dan Ukuran Perusahaan mendapatkan respon negatif dari para investor. Investor memiliki persepsi yang rendah akan hal tersebut, karena akan menimbulkan biaya tambahan yang dapat membebani kinerja keuangan perusahaan yang akan berdampak pada Nilai Perusahaan.

6) Pengujian Hipotesis Keenam
Ringkasan uji hipotesis keenam dapat dilihat pada tabel berikut:

Tabel 15. Hasil Pengujian Hipotesis Keenam

\begin{tabular}{llllcc}
\hline & Kelompok & N & Mean & t & Sig. \\
PBV & Kelompok A & 6 & 0,4167 & 3,801 & 0,000 \\
& & 8 & & & \\
& Kelompok B & 5 & 0,2688 & & \\
& & 0 & & & \\
SR & Kelompok A & 6 & 0,1297 & 2,033 & 0,044 \\
& & 8 & & & \\
& Kelompok B & 5 & 0,1087 & & \\
& & 0 & & & \\
Size & Kelompok A & 6 & 1,5026 & - & 0,000 \\
& & 8 & & 7,077 & \\
& Kelompok B & 5 & 1,5230 & & \\
& & 0 & & & \\
ROA & Kelompok A & 6 & 0,0222 & 3,112 & 0,002 \\
& & 8 & & & \\
\hline
\end{tabular}

Berdasarkan hasil uji beda pada tabel 15 terlihat bahwa seluruh variabel memiliki tingkat signifikansi dibawah 0,05. Hal ini menunjukkan bahwa variabel Nilai Perusahaan, Sustainability Report (SR), Ukuran Perusahaan, dan Profitabilitas berbeda secara signifikan antara perusahaan yang bergabung di ISSI dan perusahaan konvensional.

Keberhasilan bank Muamalat dalam mengahadapi krisis ekonomi mengakibatkan para ahli mengubah orientasi pemikirannya ke arah ekonomi Syariah. Bersamaan dengan turunnya kepercayaan nasabah pada Bank Konvensional terjadi peningkatkan kepercayaan nasabah terhadap Bank Syariah. Hal tersebut mengakibatkan nasabah mulai beralih pada Bank Syariah. 


\section{JURNAL NOMINAL / VOLUME VII NOMOR 2 / TAHUN 2018}

Selain itu, mulai banyak bermuncullan perusahaan yang beralih ke orientasi ekonomi bebasis syariah.

\section{PENUTUP}

\section{Simpulan}

Berdasarkan hasil penelitian dan pembahasan pada bab sebelumnya, dapat disimpulkan bahwa:

a. Pengungkapan Sustainability Report (SR) berpengaruh positif dan tidak signifikan terhadap Nilai Perusahaan pada perusahaan yang terdaftar di Bursa Efek Indonesia periode 20142016.

b. Ukuran Perusahaan berpengaruh negatif dan tidak signifikan terhadap Nilai Perusahaan pada perusahaan yang terdaftar di Bursa Efek Indonesia periode 2014-2016.

c. Profitabilitas tadak mampu memoderasi pengaruh Pengungkapan Sustainability Report (SR) terhadap Nilai Perusahaan pada perusahaan yang terdaftar di Bursa Efek Indonesia periode 2014-2016.

d. Profitabilitas tidak mampu memoderasi pengaruh Ukuran Perusahaan terhadap Nilai Perusahaan pada perusahaan yang terdaftar di Bursa Efek Indonesia periode 20142016.

e. Pengungkapan Sustainability Report (SR) dan Ukuran Perusahaan tidak berpengaruh secara bersama-sama terhadap Nilai Perusahaan pada perusahaan yang terdaftar di Bursa Efek Indonesia periode 2014-2016.

f. Variabel Nilai Perusahaan, Sustainability Report (SR), Ukuran Perusahaan, dan Profitabilitas berbeda secara signifikan antara perusahaan yang bergabung di ISSI dan perusahaan konvensional.

\section{Saran}

Berdasarkan hasil penelitian dan keterbatasan penelitian, peneliti dapat memberikan saran sebagai berikut:

a. Bagi Investor

Investor harus lebih selektif dalam memilih perusahaan yang akan ditanamkan modalnya. Selain itu, bagi investor dalam melakukan investasi seyogyanya tidak hanya mempertimbangkan laporan keuangan yang mencerminkan kondisi keuangan perusahaan. Akan tetapi juga mempertimbangkan tanggung jawab sosial perusahaan yang dituangkan pada Sustainability Report.

b. Bagi Perusahaan

Perusahaan diharapkan lebih memperhatikan penerapan kegiatan tanggung jawab sosial. Selain itu, perusahaan juga diharapkan mengungkapkan kegiatan tersebut secara sukarela dalam Sustainability Report sesuai dengan standar yang 


\section{JURNAL NOMINAL / VOLUME VII NOMOR 2 / TAHUN 2018}

telah ditetapkan Global Reporting

Index (GRI).

c. Bagi Peneliti Selanjutnya

1) Penelitian ini menggunakan Price to Book Value (PBV) untuk memproksikan Nilai Perusahaan. Penelitian selanjutnya diharapkan dapat menggunakan proksi lain, seperti Tobin's Q dan Price to Earning Ratio (PER). Penggunaan proksi lain diharapkan mampu menggambarkan variabel Nilai Perusahaan.

2) Penelitian ini menggunakan Return on Total Aset (ROA) untuk memproksikan Profitabilitas. Penelitian selanjutnya diharapkan dapat menggunakan proksi lain, seperti Margin Laba atas Penjualan, ROE, dan BEP. Penggunaan proksi lain diharapkan mampu menggambarkan variabel Nilai Perusahaan.

3) Penelitian ini menggunakan faktor internal untuk variabel independen dan variabel pemoderasi. Penelitian selanjutnya diharapkan dapat menggunakan variabel eksternal perusahaan, seperti tingkat inflasi, tingkat suku bunga, situasi sosial politik, dan kurs mata uang. Penggunaan variabel lain ini diharapkan mampu mendapatkan hasil yang lebih bervariasi.

\section{DAFTAR PUSTAKA}

Aditama, Fahad. (2015). "Pengaruh Ukuran Perusahaan, Kepemilikan Institusional, dan Pertunbuhan Penjualan terhadap Nilai Perusahaan dengan Kebijakan Hutang sebagai Variabel Intervening pada Perusahaan Manufaktur yang Terdaftar di BEI". Skripsi. Jurusan Akuntansi, FE, Uiversitas Negeri Semarang.

Ali, Z. (2008). Hukum Ekonomi Syariah. Jakarta: Sinar Grafika.

Arijanto, A. (2012). Etika Bisnis bagi Pelaku Bisnis: Cara Cerdas dalam Memahami Konsep dan Faktorfaktor Etika Bisnis dengan Beberapa Contoh Praktis. Jakarta: PT Rajagrafindo Persada.

Astuti, A.D \& Juwenah. (2017). Pengaruh Pengungkapan Sustainability Report terhadap Nilai Perusahaan yang tergabung dalam LQ 45 Tahun 20122013. Journal of Accounting and Finance, Vol. 2 No. 01, 301-313.

Brigham \& Houston. (2010). Dasar-Dasar Manajemen Keuangan. Jakarta: Salemba Empat.

Deriyaso, I. (2014). "Pengaruh Profitabilitas terhadap Nilai Perusahaan dengan Corporate Social Responsibility sebagai Variabel Moderating (Studi Empiris pada Perusahaan Manufaktur yang Terdaftar di Bursa Efek Indonesia)". Skripsi. Universitas Diponegoro Semarang.

Ernawan, E.R. (2011). Business Ethics. Bandung: Alfabeta.

Hadi, N. (2011). Corporate Social Responsibility. Yogyakarta: Graha Ilmu. 
JURNAL NOMINAL / VOLUME VII NOMOR 2 / TAHUN 2018

Kuncoro, M. (2003). Metode Riset untuk Bisnis dan Ekonomi. Jakarta: Erlangga.

Kusumadilaga, R. (2010). "Pengaruh Corporate Sosial Responsibility terhadap Nilai Perusahaan dengan Profitabilitas sebagai Variabel Moderating". Skripsi. Fakultas Ekonomi, Universitas Diponegoro Semarang.

Suffah, R. \& Riduwan, A. (2016). Pengaruh Profitabilitas, Leverage, Ukuran Perusahaan dan Kebijakan Dividen pada Nilai Perusahaan. Jurnal Ilmu dan Riset Akuntansi, Volume 5, Nomor 2.

Tjiptono, D \& Fakhruddin. (2012). Pasar Modal di Indonesia. Edisi Ketiga. Jakarta: Salemba Empat.

www.globalreporting.org. Diakses pada tanggal 19 Desember 2017 pukul 02:40.

www.hukumonline.com

www.idx.co.id 